\title{
ANALISIS PENGUKURAN KINERJA KEUANGAN PADA PEMERINTAH KOTA TOMOHON
}

\author{
Christian D. Sumual ${ }^{1}$, Lintje Kalangi ${ }^{2}$, Natalia Y.T Gerunggai ${ }^{3}$ \\ ${ }^{1,2,3}$ Fakultas Ekonomi dan Bisnis, Jurusan Akuntansi, Universitas Sam Ratulangi, Jl. Kampus Bahu, Manado, \\ 95115, Indonesia \\ E-mail : christiansumual11@gmail.com
}

\begin{abstract}
Information generated from financial statements will be useful if the information is understood and used by users in analyzing a report and management of local finances. For that we need to measure the financial performance of the government, how far the progress achieved by the government of Tomohon. The research was conducted in the financial management, revenue and assets of Tomohon. The data used is quantitative in the form of Budget Realization Report (LRA), the method used is quantitative to measure financial performance with Financial ratios. The results show that the financial performance of Tomohon is not good, where the financial performance in 2013-2016, for the effectiveness ratio is above $90 \%-100 \%$. While the efficiency ratio and the independence ratio per year are not running well.
\end{abstract}

Keywords: Influence of financial performance measurement

\section{PENDAHULUAN}

Pengelolaan keuangan daerah sangat besar pengaruhnya terhadap perkembangan suatu daerah untuk mengetahui tingkat target capaian keuangan daerah tersebut. Untuk itu pengelolaan keuangan daerah harus dilakukan secara ekonomis efisien dan efektif atau memenuhi value for money serta transparansi, akuntabilitas, keadilan dan partisipasi masyarakat agar bisa mendorong pertumbuhan ekonomi yang selanjutnya bisa mengurangi jumlah penganggaran serta menurunkan tingkat kemiskinan. Untuk pengelolaan daerah tidak hanya dibutuhkan sumber daya manusia, tetapi juga sumber daya ekonomi berupa keuangan yang dituangkan dalam suatu anggaran pemerintah daerah.

Kondisi ini mendorong peningkatan kebutuhan adanya suatu pengukuran kinerja keuangan terhadap para penyelenggara negara yang telah menerima amanat dari rakyat. Pengukuran tersebut akan melihat seberapa jauh kinerja yang telah dihasilkan dalam suatu periode tertentu dibandingkan dengan yang telah direncanakan.

Dengan dilakukannya pengukuran kinerja keuangan tersebut maka dapat dipastikan apakah pengambilan keputusan sudah dilakukan secara tepat dan objektif. Selain itu, dapat juga mengevaluasi pelaksanaan kinerja serta menentukan tindakan apa yang akan dilakukan selanjutnya untuk memperbaiki kinerja pada periode berikutnya.

Dalam PSAP No.4, keberhasilan pencapaian kinerja dapat diketahui berdasarkan tingkat efisiensi dan tingkat efektivitas. Pengukuran kinerja keuangan juga harus dikaitkan dengan tujuan dan sasaran dari rencana strategis pemerintah dan indikator yang digunakan harus sesuai dengan peraturan perundang-undangan yang berlaku.

Sistem pengukuran kinerja sektor publik merupakan suatu sistem yang bertujuan untuk membantu manajer publik menilai pencapaian suatu strategi, hal ini menekankan pada peranan manajer publik agar memberikan pelayanan yang berkualitas kepada masyarakat, mendorong meningkatkan pengelolaan manajerial yang bersih dari korupsi.

Dalam mengukur kinerja keuangan pemerintah, harus diselenggarakan berdasarkan peraturan perundang-undangan yang mengatur tentang keuangan daerah, antara lain:

(a) Undang-undang Nomor 17 tahun 2003 tentang Keuangan Daerah 
(b) Undang-undang Nomor 32 tahun 2004 tentang Pemerintah Daerah

(c) Peraturan Menteri Dalam Negeri nomor 13 tahun 2006 tentang Pedoman Pengelolaan Keuangan Daerah

(d) Peraturan Pemerintah nomor 58 tahun 2005 tentang Pengelolaan Keuangan daerah

(e) Instruksi Presiden Republik Indonesia nomor 7 tahun 1999 tentang Akuntabilitas Kinerja Instansi Pemerintah

Hal ini tercantum dalam Pasal 1 ayat (5) PP Nomor 24 tahun 2005 tentang SAP yang menyebutkan bahwa Sistem Akuntansi Pemerintahan adalah serangkaian prosedur manual maupun yang terkomputerisasi, mulai dari pengumpulan data, pencatatan, pengikhtisran, dan pelaporan posisi keuangan dan operasi keuangan organisasi dalam hal ini pemerintah daerah.

Pemerintah Kota Tomohon memiliki peran yang sangat penting dalam mengembang amanat Undang-undang Nomor 32 Tahun 2004 tentang pemerintah daerah, yaitu dengan mengacu pada pasal 23 yang menyebutkan bahwa : Hak dan kewajiban daerah sebagaimana dimaksud dalam pasal 21 dan pasal 22 diwujudkan dalam bentuk rencana kerja pemerintah daerah dan dijabarkan dalam bentuk pendapatan, belanja, dan pembiayaan daerah yang dikelola dalam sistem pengelolaan keuangan daerah. Pengelolaan keuangan dimaksudkan adalah pengelolaan keuangan secara efisien, efektif, transparan, akuntabel, tertib, adil, patut dan taat pada peraturan perundang-undangan yang berlaku (Pasal 23 ayat 2, UU No. 32 Tahun 2004). Dinas Pengelolaan Keuangan, Pendapatan dan Aset Pemerintah Kota Tomohon mempunyai tugas pokok melaksanakan urusan tugas pokok pemerintah daerah dalam menyusun dan melaksanakan kebijakan daerah di bidang pendapatan, pengelolaan keuangan dan aset daerah. Tujuan penelitian ini adalah untuk menganalisis dan mengukur Kinerja Keuangan yang berada Kota Tomohon.

\section{TINJAUAN PUSTAKA}

\subsection{Konsep Akuntansi}

Definisi akuntansi menurut American Accounting Association adalah suatu proses mengidentifikasi, mengukur dan melaporkan informasi ekonomi untuk memungkinkan adanya penilaian dan keputusan yang jelas serta tegas bagi pihak yang menggunakan informasi tersebut, PuraRahman (2013: 4). Palilingan (2015),akuntansi didefinisikan pula sebagai perangkat pengetahuan yang mempelajari perekayasaan dalam penyediaan jasa, berupa informasi keuangan dari suatu unit organisasi dan cara penyampaian (pelaporan) informasi tersebut kepada pihak yang berkepentingan.

\subsection{Konsep Akuntansi Pemerintahan}

Menurut Halim (2008: 35) definisi akuntansi pemerintahan daerah yang disebutnya sebagai Akuntansi Keuangan Daerah adalah proses pengidentifikasian, pengukuran, pencatatan dan pelaporan transaksi ekonomi (keuangan) dari entitas pemerintah daerah (kabupaten, kota atau provinsi) yang dijadikan informasi dalam rangka pengambilan keputusan ekonomi oleh pihak-pihak eksternal pemerintah daerah yang memerlukan. Rondonuwu (2015) berdasarkan pengertian tentang Akuntansi Pemerintahan menurut ketiga ahli diatas, dapat disimpulkan bahwa Akuntansi Pemerintahan adalah mekanisme teknik dan analisis akuntansi yang diterapkan pada pengelolaan dana masyarakat, dan dijadikan informasi dalam rangka pengambilan keputusan ekonomi bagi yang memerlukan, selain itu juga meningkatkan kesejahteraan masyarakat dan bukan untuk mencari keuntungan finansial.

\subsection{Standar Akuntansi Pemerintahan}

Sagay (2013) dengan demikian SAP merupakan persyaratan yang mempunyai kekuatan hukum dalam upaya meningkatkan kualitas laporan keuangan pemerintah di Indonesia. SAP dinyatakan dalam bentuk Persyaratan Standar Akuntansi Pemerintahan (PSAP) yang dilengkapi dengan Pengantar Standar Akuntansi Pemerintahan, yaitu uraian yang memuat latar belakang penyusunan SAP. 


\subsection{Sistem Akuntansi Pemeintahan Daerah}

Tampi (2014), untuk menyelenggarakan akuntansi pemerintahan daerah, kepala daerah menetapkan sistem akuntansi pemerintahan daerah dengan mengacu pada peraturan daerah tentang pokok-pokok pengelolaan keuangan daerah, serta disusun dengan berpedoman pada prinsip pengendalian intern dan standar akuntansi pemerintahan.

\subsection{Pengertian Kinerja}

Wibowo (2011:229) Menjelaskan bahwa pengukuran terhadap kinerja perlu dilakukan untuk mengetahui apakah selama pelaksanaan kinerja terdapat deviasi dari rencana yang telah ditentukan, atau apakah kinerja dapat dilakukan sesuai jadwal waku yang ditentukan, atau apakah hasil kinerja telah tercapai sesuai dengan yang diharapkan.

\subsubsection{Indikator Pengukuran Kinerja}

Menurut Hersey, dkk dalam Wibowo (2011: 102) terdapat 7 indikator kinerja:

1. Tujuan

Tujuan menunjukkan ke arah mana kinerja harus dilakukan. Atas dasar arah tersebut, dilakukan kinerja untuk mencapai tujuan. Kinerja individu maupun organisasi dikatakan berhasil apabila dapat mencapai tujuan yang diinginkan.

2. Standar

Standar merupakan suatu ukuran apakah tujuan yang diinginkan dapat dicapai. Tanpa standar, tidak dapat diketahui kapan suatu tujuan tercapai. Kinerja seseorang dikatakan berhasil apabila mampu mencapai standar yang ditentukan atau disepakati bersama atasan atau bawahan.

\section{Umpan Balik}

Umpan balik merupakan masukan yang dipergunakan untuk mengukur kemajuan kinerja, standar kinerja, dan pencapaian tujuan. Dengan umpan balik dilakukan evaluasi terhadap kinerja dan sebagai hasilnya dapat dilakukan perbaikan kinerja.

4. Alat atau Sarana

Alat atau sarana merupakan factor penunjang untuk pencapaian tujuan. Tanpa alat atau sarana, tugas pekerjaan spesifik tidak dapat dilakukan dan tujuan tidak dapat diselesaikan sebagaimana seharusnya.

5. Kompetensi

Kompetensi merupakan kemampuan yang dimiliki seseorang untuk menjalankan pekerjaan yang diberkan kepadanya dengan baik. Kompetensi memungkinkan seseorang mewujudkan tugas yang berkaitan dengan pekerjaan yang diperlukan untuk mencapai tujuan.

\section{Motif}

Motif merupakan alasan atau pendorong bagi seseorang untuk melakukan sesuatu, tanpa dorongan motif untuk mencapai tujuan, kinerja tidak akan berjalan.

7. Peluang

Pekerja perlu mendapatkan kesempatan untuk menunjukkan prestasi kerjanya. Tugas mendapatkan prioritas lebih tinggi, mendapat perhatian lebih banyak dan mengambil waktu yang tersedia.

\subsubsection{Tujuan Pengukuran Kinerja}

Pengukuran kinerja menurut Sinambela (2012: 187) mempunyai tiga tujuan, yaitu:

1. Membantu memperbaiki kinerja agar kegiatan terfokus pada tujuan dan sasaran program unit kerja.

2. Pengalokasian sumber daya dan pembuatan keputusan.

3. Mewujudkan pertanggungjawaban publik dan memperbaiki komunikasi kelembagaan.

\subsubsection{Aspek-Aspek Pengukuran Kinerja Sektor Publik}

Pengukuran kinerja organisasi sektor publik menurut Mohammand (2009: 31) meliputi aspek-aspek, antara lain: 
1. Kelompok masukan (input); segala sesuatu yang dibutuhkan agar pelaksanaan kegiatan dapat berjalan untuk menghasilkan keluaran.

2. Kelompok proses (process); ukuran kegiatan, baik dari segi kecepatan, ketepatan, maupun tingkat akurasi pelaksanaan kegiatan tersebut.

3. Kelompok keluaran (output); sesuatu yang diharapkan langsung dapat dicapai dari suatu kegiatan yang dapat berwujud (tangible) maupun tidak berwujud (intangible).

4. Kelompok hasil (outcome); segala sesuatu yang mencerminkan berfungsinya keluaran kegiatan pada jangka menengah yang mempunyai efek langsung.

5. Kelompok manfaat (benefit); sesuatu yang terkait dengan tujuan akhir dari pelaksanaan kegiatan.

6. Kelompok dampak (impact); pengaruh yang ditimbulkan baik positif maupun negatif.

\subsubsection{Pengukuran Kinerja}

Ayu (2014), menyatakan laporan kinerja dihasilkan dari suatu sistem akuntabilitas kinerja instansi pemerintah yang diselenggarakan oleh setiap Entitas Pelaporan dan/atau Entitas Akuntansi.

\subsection{Laporan Keuangan Pemerintahan Daerah}

Menurut Mahmudi (2010:9), meskipun laporan keuangan sudah bersifat general purposive, artinya dibuat lebih umum dan sesederhana mungkin untuk memenuhi kebutuhan informasi semua pihak, tetapi tidak semua pembaca laporan dapat memahami laporan tersebut dengan baik.

\subsubsection{Karakteristik Kualitatif Laporan Keuangan}

Berdasarkan Standar Akuntansi Pemerintah, karakteristik kualitatif laporan keuangan adalah ukuran-ukuran normatif yang perlu diwujudkan dalam informasi akuntansi sehingga dapat memenuhi tujuannya. Keempat karakteristik berikut ini merupakan persyaratan normatif yang diperlukan agar laporan keuangan pemerintah dapat memenuhi kualitas yang dikehendaki:

1. Relevan.

2. Andal.

3. Dapat dipahami.

4. Dapat dibandingkan.

\subsubsection{Peranan Pelaporan Keuangan}

Menurut Halim (2013:20) tujuan pelaporan keuangan pemerintah adalah menyajikan informasi yang berguna untuk pengambilan keputusan dan untuk menunjukkan akuntabilitas entitas pelaporan atas sumber daya yang dipercayakan.

\subsubsection{Tujuan Pelaporan Keuangan Pemerintah}

Menurut Peraturan Pemerintah Nomor 71 Tahun 2010 tentang Standar Akuntansi Pemerintahan, pelaporan keuangan pemerintah seharusnya menyajikan informasi yang bermanfaat bagi para pengguna dalam menilai akuntabilitas dan membuat keputusan ekonomi, sosial, maupun politik.

\subsection{Analisis Rasio Keuangan}

1. Rasio Kemandirian

$$
\text { Rasio Kemandirian }=\frac{\text { Pendapatan Asli Daerah }}{\text { Bantuan Pusat dan Pinjaman }} \times 100 \%
$$

Atau

$$
\text { Rasio Kemandirian }=\frac{\text { Pendapatan Asli Daerah }}{\text { Total Pendapatan }} \times 100 \%
$$


Menurut Mahmudi (2010:142) Rasio kemandirian keuangan daerah atau yang sering disebut sebagai otonomi fiskal menunjukkan daerah dalam membiayai sendiri kegiatan pemerintahan, pembangunan, dan pelayanan kepada masyarakat yang telah membayar pajak dan retribusi sebagai sumber pendapatan yang diperlukan daerah.

2. Rasio Efektivitas

$$
\text { Rasio Efektivitas }=\quad \frac{\text { Realisasi Penerimaan PAD }}{\text { Target Penerimaan PAD }} \times 100 \%
$$

Menurut Mahmudi (2010:143), pengertian efektivitas berhubungan dengan derajat keberhasilan suatu operasi pada sektor publik sehingga suatu kegiatan dikatakan efektif jika kegiatan tersebut mempunyai pengaruh besar terhadap kemampuan menyediakan pelayanan masyarakat yang merupakan sasaran yang telah ditetapkan sebelumnya.

3. Rasio Efesiensi

$$
\text { Rasio Efisiensi }=\frac{\text { Realisasi Pengeluaran }}{\text { Realisasi Penerimaan }} \times 100 \%
$$

Menurut Mahmudi (2010:146), rasio efisiensi adalah rasio yang menggambarkan perbandingan antara output dan input atau realisasi pengeluaran dengan realisasi penerimaan daerah. Semakin kecil rasio ini, maka semakin efisien, begitu pula sebaliknya. Dalam hal ini dengan mengasumsikan bahwa pengeluaran yang dibelanjakan sesuai dengan peruntukkannya dan memenuhi dari apa yang direncanakan.

\subsection{Pengertian Struktur dan APBD}

Menurut Standar Akuntansi Pemerintahan, APBD adalah rencana keuangan tahunan pemerintahan daerah yang disetujui oleh Dewan Perwakilan Rakyat Daerah. Berdasarkan Peraturan Menteri Dalam Negeri Nomor 13 tahun 2006 tentang Pedoman Pengelolaan Keuangan Daerah, struktur APBD merupakan satu kesatuan yang terdiri dari:

a. Pendapatan daerah, meliputi semua penerimaan uang melalui rekening kas umum daerah, yang menambah ekuitas dana, merupakan hak daerah dalam satu tahun tahun anggaran dan tidak perlu dibayar kembali oleh daerah.

Pendapatan daerah dikelompokkan atas:

1. Pendapatan Asli daerah (Pajak daerah, Retribusi daerah, hasil pengelolaan kekayaan daerah yang dipisahkan, dan lain-lain pendapatan asli daerah yang sah).

2. Dana Perimbangan (Dana bagi hasil, dana alokasi umum, dan dana alokasi khusus).

3. Lain-lain Pendapatan Daerah yang Sah (Hibah).

b. Belanja daerah, meliputi semua pengeluaran dari rekening kas umum daerah yang mengurangi ekuitas dana, merupakan kewajiban daerah dalam satu tahun anggaran dan tidak akan diperoleh pembayarannya kembali oleh daerah.

Belanja dikelompokkan menjadi:

1. Belanja Tidak Langsung, yaitu belanja yang dianggarkan tidak terkait secara langsung dengan pelaksanaan program dan kegiatan (belanja pegawai, bunga, subsidi, hibah, bantuan sosial, belanja bagi hasil, bantuan keuangan, dan belanja tidak terduga).

2. Belanja Langsung, yaitu belanja yang dianggarkan terkait secara langsung dengan pelaksanaan program dan kegiatan (belanja pegawai, belanja barang dan jasa, dan belanja modal).

c. Pembiayaan daerah, meliputi semua transaksi keuangan untuk menutup defisit atau memanfaatkan surplus.

Pembiayaan daerah terdiri dari:

1. Penerimaan pembiayaan.

2. Pengeluaran pembiayaan. 


\subsection{Penelitian Terdahulu}

Wahidah Niken Kusumadewi,SE (2016) Judul Penelitian Analisis Kinerja Keuangan Pemerintah Minahasa Utara Tahun 2012-2014, tujuan penelitian ini untuk mengukur dan menganalisis kinerja keuangan yang ada di pemerintah Minahasa Utara. Metode yang digunakan yaitu berupa deskriptif kualitatif. Hasil penelitian menunjukkan dalam menganalisis kinerja keuangan pemerintah kabupaten Minahasa Utara belum mengoptimalkan keserasian belanja yang dipakai. Terdapat persamaan dan perbedaan dalam penelitian yaitu dalam persamaan ,sama-sama menganalisis kinerja keuangan dipemerintahan sedangkan perbedaan terdapat dalam objek dan metode yang dipakai.

\section{METODE PENELITIAN}

\subsection{Jenis Penelitian}

Jenis penelitian yang dilakukan berupa penelitian deskriptif, Kuncoro (2009: 12) menjelaskan bahwa penelitian deskriptif meliputi pengumpulan data atau menjawab pertanyaan mengenai status terakhir dari subjek penelitian. Tipe yang paling umum dari penelitian deskriptif ini meliputi penilaian sikap atau pendapat terhadap individu, organisasi, keadaan ataupun prosedur.

\subsection{Tempat dan Waktu Penelitian}

Penelitian ini dilakukan pada Pemerintah Kota Tomohon di Dinas pengelolaan keuangan , Pendapatan dan Aset kota Tomohon dan waktu penelitian dilakukan pada bulan Januari-Juli.

\subsection{Prosedur Penelitian}

Prosedur yang dilakukan dalam penelitian ini adalah :

1. Mengidentifikasikan latar belakang masalah dalam penelitian ini.

2. Merumuskan masalah dalam penelitian ini.

3. Mencari literatur -literatur yang terkait dalam penelitian ini.

4. Mengumpulkan data-data yang terkait dalam penelitian di Pemerintah Kota Tomohon.

5. Menganalisis data-data yang terkait dengan penelitian ini.

6. Menarik kesimpulan dan memberikan saran berdasarkan pembahasan dalam penelitian ini.

\subsection{Metode Pengumpulan Data}

\subsubsection{Jenis Data}

Dalam penelitian ini data yang digunakan adalah data kuantitatif, yaitu berupa Laporan Realisasi Anggaran.

\subsubsection{Sumber Data}

Sumber data yang digunakan dalam penelitian ini adalah data primer. Data primer berupa wawancara dengan Kepala Dinas Pengelolaan Keuangan, Pendapatan dan Aset Kota Tomohon dan menerima berupa Laporan Realisasi Anggaran (LRA) dari Dinas Pengelolaan Keuangan, Pendapatan dan Aset Kota Tomohon tahun 2013-2016.

\subsubsection{Teknik Pengumpulan Data}

Dalam penelitian ini teknik pengumpulan data dilakukan melalui tahap-tahap sebagai berikut:

1. Field Research (Penelitian lapangan)

Yaitu mengumpulkan data-data primer dengan datang langsung ke Dinas Pengelolaan Keuangan, Pendapatan dan Aset Kota Tomohon melakukan:

a. Wawancara, dengan bertanya secara langsung pegawai pada Dinas Pengelolaan Keuangan, Pendapatan dan Aset Kota Tomohon.

b. Dokumentasi, dilakukan dengan melakukan penelusuran terhadap dokumendokumen yang mendukung penelitian. 
c. Media elektronik, ini dilakukan dengan mencari data dalam internet yang mendukung penelitian ini

\subsection{Metode Analisis}

Metode analisis yang digunakan untuk membahas permasalahan dalam penelitian ini adalah analisis deskriptif. Menurut Fidel (2013), analisis deskriptif adalah kegiatan dimana tingkat pekerjaannya mencakup cara-cara pengumpulan, menyusun atau mengatur, mengelola, menyajikan dan menganalisis data angka agar dapat memberikan gambaran yang teratur, ringkas dan jelas mengenai keadaan, peristiwa atau gejala tertentu sehingga dapat ditarik pengertian atau makna tertentu.

\subsection{Metode Perhitungan}

Untuk mengukur kinerja keuangan dalam organisasi pemerintahan ada beberapa metode perhitungan rasio pengukuran kinerja, yaitu:

1) Rasio Kemandirian

2) Rasio Efektivitas

3) Rasio Efisiensi

\section{HASIL ANALISIS DAN PEMBAHASAN}

\subsection{Gambaran Umum}

\subsubsection{Profil Objek Penelitian.}

Kota Tomohon adalah salah satu kota di Provinsi Sulawesi Utara, Indonesia. Sebelum tahun 2003 merupakan salah satu kecamatan di Kabupaten Minahasa. Dalam perkembangannya, Tomohon mengalami banyak sekali kemajuan, sehingga ada aspirasi dan warganya untuk meningkatkan status Tomohon menjadi sebuah kota. Tomohon menjadi daerah otonom (kota) dengan disahkannya Undang-Undang Nomor 10 Tahun 2003 tentang pembentukan Kabupaten Minahasa Selatan dan Kota Tomohon di Provinsi Sulawesi Utara oleh DPR RI, namun peresmiannya baru pada tanggal 4 Agustus 2003. Beberapa Visi dan Misi yang sudah pernah di terapkan oleh Walikota sebelumnya, tapi dengan seiring waktu yang berjalan dan berkembangnya teknologi maka Walikota untuk periode 2016-2020 telah memikirkan sebuah Visi dan Misi untuk membawa Kota Tomohon semakin maju dan berkembang .

"Terwujudnya Masyarakat Kota Tomohon yang Religius Berdaya Saing, Demokratis, Sejahtera , Berbudaya dan Berwawasan Lingkungan, Menuju Kota Wisata Dunia”.

Untuk mendukung dan mewujudkan Visi tersebut, maka Pemerintah Kota Tomohon menetapkan 7(Tujuh) Misi yang harus dilaksanakan sebagai berikut :

1. Mewujudkan Masyarakat Berahlak Mulia, Bermoral, Beretika Melalui Pendidikan Yang Unggul.

2. Mewujudkan Daerah Yang Berdaya Saing Dan Mandiri.

3. Mewujudkan Kota Tomohon Yang Demokratis Berdasarkan Hukum

4. Mewujudkan Kota Tomohon Yang Aman, Damai Dan Bersatu Dalam Keragaman.

5. Mewujudkan Pembangunan Berwawasan Lingkungan Yang Berkelanjutan.

6. Mewujudkan kota Tomohon Sebagai Kota Wisata Dunia

7. Mewujudkan Masyarakat Kota Yang Berkepribadian Dalam Kebudayaan. 


\subsection{Hasil Penelitian}

Hasil Penelitian dan Pembahasan

Tabel 1. Laporan Realisasi Anggaran Tahun 2013-2016

\begin{tabular}{lcccc}
\hline & $\mathbf{2 0 1 3}$ & $\mathbf{2 0 1 4}$ & $\mathbf{2 0 1 5}$ & $\mathbf{2 0 1 6}$ \\
\hline Total & & & & \\
$\begin{array}{l}\text { Pendapatan } \\
\text { Daerah }\end{array}$ & 461.311 .984 .055 & 528.035 .636 .453 & 554.515 .977 .321 & 656.167 .048 .362 \\
Target PAD & 12.700 .975 .000 & 21.206 .931 .368 & 25.039 .931 .368 & 26.383 .043 .368 \\
$\begin{array}{l}\text { Realisasi PAD } \\
\text { Realisasi }\end{array}$ & 13.945 .339 .275 & 20.100 .568 .636 & 24.657 .382 .659 & 26.011 .141 .966 \\
$\begin{array}{l}\text { Pengeluaran } \\
\text { Bantuan Pusat } \\
\text { dan Pinjaman }\end{array}$ & 451.402 .758 .551 & 514.569 .939 .388 & 555.223 .362 .453 & 620.959 .253 .455 \\
\hline Sund & 330.892 .646 .000 & 376.334 .135 .000 & 360.894 .361 .000 & 401.799 .456 .000 \\
\hline
\end{tabular}

Sumber:Dinas Pengelolaan Keuangan, Pendapatan dan Aset Kota Tomohon 2016.

Dapat dilihat hasil dari penelitian menunjukkan pada tahun 2013 total pendapatan daerah Kota Tomohon sebesar Rp.461.311.984.055, ditahun 2014 meningkat sebesar Rp.528.035.636.453, kemudian ditahun 2015 kembali meningkat sebesar Rp.554.515.977.321, dan ditahun 2016 meningkat menjadi Rp.656.167.048.362. Target PAD Kota Tomohon pada tahun 2013 sebesar Rp.12.700.975.000, pada tahun 2014 meningkat menjadi Rp.21.206.931.368, pada tahun 2015 meningkat lagi sebesar Rp.25.039.931.368, pada tahun 2016 meningkat sebesar Rp.26.383.043.368. Realisasi PAD Kota Tomohon pada tahun 2013 sebesar Rp.13.945.339.275, dan pada tahun 2014 meningkat sebesar Rp.20.100.568.636, pada tahun 2015 meningkat lagi sebesar Rp.24.657.382.659, dan pada akhir tahun 2016 meningkat menjadi Rp.26.011.141.966. Realisasi Pengeluaran Kota Tomohon pada tahun 2013 sebesar Rp.451.402.758.551, dan pada tahun 2014 meningkat menjadi Rp.514.569.939.388, pada tahun 2015 meningkat juga sebesar Rp.555.223.362.453, dan pada akhir tahun 2016 meningkat menjadi Rp.620.959.253.455. Bantuan Pusat dan Pinjaman Kota Tomohon pada tahun 2013 sebesar Rp.330.892.646.000, dan pada tahun 2014 meningkat menjadi Rp.376.334.135.000, pada tahun 2015 menurun sebesar Rp.360.894.361.000 dan pada akhir tahun kembali lagi meningkat menjadi Rp.401.799.456.000.

Tabel 2. Rasio Kemandirian

\begin{tabular}{ccccc}
\hline Rasio keuangan & $\begin{array}{c}\text { Tahun 2013 } \\
(\mathbf{\%})\end{array}$ & $\begin{array}{c}\text { Tahun 2014 } \\
\mathbf{( \% )}\end{array}$ & $\begin{array}{c}\text { Tahun 2015 } \\
\mathbf{( \% )}\end{array}$ & $\begin{array}{c}\text { Tahun 2016 } \\
\mathbf{( \% )}\end{array}$ \\
\hline $\begin{array}{c}\text { Rasio } \\
\text { Kemandirian }\end{array}$ & $0,38 \%$ & $0,56 \%$ & $0,68 \%$ & $0,65 \%$ \\
\hline Sumber $:$ Data Olahan 2016 & & & \\
\hline
\end{tabular}

Hasil perhitungan dengan menggunakan analisis perbandingan rasio kemandirian dapat diketahui bahwa kinerja keuangan yang ada di Kota Tomohon dari tahun 2013-2015 bisa dibilang baik karena ditiap tahunnya meningkat tapi pada tahun 2016 menurun dikarenakan adanya bantuan dan pinjaman yang dipakai untuk menunjang hasil pendapatan asli daerah. 
Tabel 3. Rasio Efektivitas

\begin{tabular}{ccccc}
\hline $\begin{array}{c}\text { Rasio } \\
\text { Keuangan }\end{array}$ & $\begin{array}{c}\text { Tahun 2013 } \\
(\boldsymbol{\%})\end{array}$ & $\begin{array}{c}\text { Tahun 2014 } \\
(\boldsymbol{\%})\end{array}$ & $\begin{array}{c}\text { Tahun 2015 } \\
(\boldsymbol{\%})\end{array}$ & $\begin{array}{c}\text { Tahun 2016 } \\
(\boldsymbol{\%})\end{array}$ \\
\hline Rasio Efektivitas & $109,79 \%$ & $94,78 \%$ & $98,47 \%$ & $98,59 \%$ \\
\hline Sumber : Data Olahan 2016 & & &
\end{tabular}

Hasil perhitungan dengan menggunakan analisis perbandingan rasio efektivitas dapat diketahui bahwa kinerja keuangan yang ada di Kota Tomohon dari tahun 2013-2016 sangatlah efektif karena hasil yang di dapat berada diatas rata-rata 90\%-100\%. Ini menunjukkan bahwa kinerja keuangan yang ada di Kota Tomohon sangatlah efektif.

Tabel 4. Rasio Efesiensi

\begin{tabular}{lcccc}
\hline Rasio keuangan & $\begin{array}{c}\text { Tahun 2013 } \\
(\boldsymbol{\%})\end{array}$ & $\begin{array}{c}\text { Tahun 2014 } \\
(\boldsymbol{\%})\end{array}$ & $\begin{array}{c}\text { Tahun 2015 } \\
(\boldsymbol{\%})\end{array}$ & $\begin{array}{c}\text { Tahun 2016 } \\
(\boldsymbol{\%})\end{array}$ \\
\hline Rasio Efisiensi & $97,85 \%$ & $97,44 \%$ & $100,12 \%$ & $94,63 \%$ \\
\hline
\end{tabular}

Sumber : Data Olahan 2016

Hasil perhitungan dengan menggunakan analisis perbandingan rasio efesiensi dapat diketahui bahwa kinerja keuangan yang ada di Kota Tomohon dari tahun 2013-2016 tidak efesien, karena hasil yang menunjukkan rata-rata 90\%-100\%. Hal ini dikarenakan pengeluaran yang dipakai tidak sesuai dengan pendapatan yang diharapkan.

\section{KESIMPULAN DAN SARAN}

\subsection{Kesimpulan}

Selama tahun 2013-2016 Kota Tomohon hanya mendapatkan predikat sebagai Kota yang efektif karena banyak target yang telah dicapai, tapi untuk pertumbuhan kemandirian dan efesiensi Kota Tomohon belum memenuhi sesuai standar yang diinginkan. Oleh karena itu dapat dikatakan bahwa kinerja keuangan Kota Tomohon kurang baik.

\subsection{Saran}

Berdasarkan hasil penelitian dan pembahasan tentang kinerja keuangan yang berada dipemerintah Kota Tomohon menggunakan rasio keuangan, penulis mengemukakan saran sebagai berikut:

1. Bagi pemerintah Kota Tomohon diharapkan lebih efisien lagi dalam mengeluarkan biaya yang ada atau setidaknya mencoba mengorbankan semininal mungkin biaya untuk bisa mendapat hasil yang maksimal.

2. Untuk kemandirian diharapkan juga pemerintah bisa mengurangi ketergantungan terhadap bantuan pemerintah pusat dan mencoba memaksimalkan pendapatan daerah yang ada, berupa bisa mengelolah lokasi wisata yang ada agar bisa mendukung pendapatan yang, gedung yang usang diperbaiki sehingga bisa disewakan untuk dipakai berbagai acara dan memaksimalkan retribusi jasa umum berupa kesehatan dan parkir.

Penulis menyarankan untuk dapat melakukan penelitian tentang kinerja keuangan yang ada di instansi pemerintahan yang lain untuk kemudian dapat dibandingkan sehingga menjadi masukan dalam rangka penelitian kinerja keuangan yang lebih baik.

\section{DAFTAR PUSTAKA}

Ayu, Fitria., L., N., 2014. Analisis Penerapan Pp. No. 71 Tahun 2010 Dalam Penyajian Laporan Keuangan Dinas Pendapatan Pengelolaan Keuangan Dan Aset Daerah Kota Kotamobagu. Skripsi Universitas Sam Ratulangi. Manado. Vol. 2, No 4. Desember 2014. Hal $714-722$. 
Halim, Abdul 2008. Akuntansi Keuangan Daerah. Hal: 35. Edisi Refisi 3. Salemba Empat. Jakarta.

Halim, Abdul 2013. Akuntansi Keuangan Daerah. Hal: 20. Edisi keempat. Salemba Empat, Jakarta.

Mahmudi, 2010. Analisis Laporan Keuangan Pemerintah Daerah. Edisi Kedua. Hal. 142. Penerbit UPP STIM YKPN. Yogyakarta .

Mohammand Mahsun, 2009. Pengukuran Kinerja Sektor Publik. Hal. 31. Edisi pertama, BPFE. Yogyakarta.

Palilingan, Anastasia, 2015. Analisis Kinerja Belanja Dalam Laporan Realisasi Anggaran (Lra) Pada Dinas Pendapatan Kota Manado. Skripsi Universitas Sam Ratulangi Manado. Vol. 3, No. 1. Maret 2015. Hal. 17 -25. ISSN 2303 - 1174.

Pura, Rahman. 2013. Pengantar Akuntansi 1 Pendekatan Siklus Akuntansi. Hal. 4. Penerbit Erlangga. Jakarta

Rondonuwu, Ritno, 2015. Analisis Efisiensi Dan Efektivitas Pengelolaan Keuangan Daerah Pada Dinas Pendapatan Daerah Kabupaten Minahasa. Universitas Sam Ratulangi Manado. Vol. 3, No 4. Desember 2015. Hal. 23 - 32. ISSN. 2303 - 1174.

Sagay, Brian. 2013. Kinerja Pemerintah Daerah Dalam Pengelolaan Anggaran Pendapatan dan Belanja Kabupaten Minahasa Selatan. Skripsi Universitas Sam Ratulangi. Manado. Vol. 1, No 3. September 2013. Hal. 1165 - 1174. ISSN. 2303 - 1174.

Sinambela, Lijan Poltak. 2012. Kinerja Pegawai: Teori Pengukuran dan Implikasi. Hal. 186 - 187. Yogyakarta : Graha Ilmu

Tampi, Julio., Y. 2014. Penerapan Akuntansi Untuk Pembiayaan Daerah Pada Dppkad Kabupaten Minahasa Tenggara. Skripsi Universitas Sam Ratulangi Manado. Vol. 2, No 3. September 2014. Hal. 438 - 447. ISSN. 2303 - 1174.

Wibowo, 2011. Manajemen Perubahan. Hal. 7, 102, 229. Jakarta: PT. Raja Grafindo Persada. 